\title{
Negeri Pemuja Iklan
}

\author{
Wendi Ahmad Wabyudi
}

S edikit bernostalgia dengan fenomena yang terjadi pasca Perang Dunia II, yang munculnya model penjajahan baru berupa perlombaan penyebaran ideologi dua negara adikuasa yang menjadi pemenang dari Perang Dunia II, yaitu Uni Soviet yang menganut paham Komunisme dan Amerika Serikat dengan paham Kapitalisme. Siapa yang menjadi korban dari perseteruan tersebut? Secara khusus yang menjadi target perseteruan tersebut adalah negara berkembang yang salah satunya yaitu Indonesia. Dampaknya bagi Indonesia, silahkan berkaca pada dua era Pemerintahan di Indonesia yaitu Orde Lama dan Orde Baru atau lebih khususnya bisa dilihat dari tragedi Gerakan 30 September 1965.

Mari kita tinggalkan kisah di dua rezim pemerintahan tersebut dan masuk ke era Reformasi atau Indonesia abad ke-21, namun dengan tema cerita yang sama yaitu tentang penjajahan. Fenomena yang terjadi pada abad ini adalah semua orang berbicara tentang merdeka tetapi tersenyum bahagia menikmati hidup dalam penjajahan. Penjajahan yang dimaksud adalah penjajahan yang tidak disadari oleh yang dijajah kalau ia sedang dijajah atau istilah yang lebih ilmiahnya yaitu hegemoni. Menurut Antonio Gramsci, Hegemoni adalah sarana kultural maupun ideologis kelas dominan untuk melestarikan dominasinya dengan mengamankan "persetujuan spontan" kelompok-kelompok subordinat melalui penciptaan negosiasi-negosiasi konsensus politik maupun ideologis yang menyusup ke dalam kelompok-kelompok dominan maupun yang didominasi. Atau sederhananya yaitu cara menindas yang membuat budak pun menjadi tertawa bahagia.

Dampak dari hegemoni pada abad ini ialah masyarakat Indonesia dengan bangga terjebak dalam pola hidup konsumerisme dan hedonisme yang tinggi bahkan bisa dikatakan tak tahu arah. Dampak ini bukan hanya serta merta karena kuatnya pengaruh dari luar Indonesia, tetapi juga karena keropos dari dalam tubuh masyarakat Indonesia sendiri yaitu mental yang bobrok. Seperti yang pernah disinggung oleh Reza A.A. Wattimena dalam bukunya yang berjudul 'Bahagia Kenapa Tidak?', ada tiga mental peninggalan kolonial yang setia dipertahankan oleh masyarakat Indonesia, yaitu mental budak, abdi, dan minder. Mental budak berarti, orang malas atau tidak mau berpikir mandiri, dan menyerahkan keputusan hidupnya pada apa kata kelompok. Orang semacam ini tidak lebih sebagai budak yang rindu untuk dikuasai dan ditaklukkan, karena tidak mau berpikir mandiri. Mental budak terwujud nyata di dalam sikap abdi. Sikap abdi berarti, orang lebih senang disuruh dan diperintah, daripada memutuskan sendiri, apa yang mesti ia lakukan. Orang lebih senang tunduk pada kata orang lain, daripada mempertimbangkan sendiri, apa yang baik dan buruk bagi dirinya. Sikap abdi yang meluas akan menciptakan bangsa budak yang bergantung dan tunduk pada bangsa asing. Di hadapan bangsa asing, kita merasa minder dan rendah diri. Kita merasa, apapun yang orang asing lakukan selalu lebih baik dari yang kita lakukan. Sikap minder, mental budak dan sikap abdi saling terkait satu sama lain.

Ciri-ciri dari perwujudan dari ketiga mental tersebut ialah kita lebih senang barang buatan luar negeri, daripada barang buatan dalam negeri, walaupun mutunya sama. Ada rasa bangga dan gengsi, ketika kita menggunakan produk luar negeri yang mutunya tak lebih bagus dari mutu produk dalam negeri. Bahkan yang lebih ekstremnya adalah kita lalu membenci dan mencerca bangsa sendiri dan malah dengan bangga dan senang hati memuja bangsa lain, tanpa tolok ukur yang obyektif. Itu begitu jelas terlihat dalam kasus pernikahan Bayu Kumara yang notabenenya adalah pribumi yang memiliki wajah yang bisa dibilang biasa-biasa saja dengan Jennifer yang 
merupakan perempuan Barat (Eropa) yang memiliki paras cantik yang belum lama ini begitu sangat booming. Hampir semua netizen menggunjingkannya karena banyak masyarakat yang menganggap itu hal yang di luar nalar.

Pertanyaannya, apa yang salah dengan pernikahan mereka? Begitu tabukah seorang Pribumi menikahi gadis Barat (Eropa)? Bukankah hakikatnya mereka sama-sama manusia, yang satu laki-laki dan yang satu adalah perempuan? Lalu mengapa memberi jarak begitu jauh antara Pribumi dan Barat, yang secara tidak langsung kita malah merendahkan bangsa kita sendiri yaitu Bayu Kumara? Mungkin kita masih terjebak dalam pembagian kasta yang pernah diciptakan kolonial yaitu Eropa, Timur asing (Cina, India, dan Arab), dan Pribumi sebagai kelas paling bawah, sehingga mental budak, abdi, dan minder itu masih terus coba kita lestarikan.

Dengan didukung penuh oleh fondasi mental yang digambarkan di atas, pihak asing dengan begitu mudah melakukan hegemoninya terhadap kita. Salah satu cara yang dilakukan adalah propaganda melalui iklan. Iklan merupakan cara yang ampuh untuk mengubah atau mempengaruhi pilihan orang dalam menentukan sesuatu, dan paling penting untuk membuat orang rajin dan ketagihan berbelanja. Pada dasarnya iklan produk atau jasa memang tidak akan pernah bisa jujur. Bahkan iklan juga dapat 'membunuh' kemanusiaan tanpa rasa sakit. Tak pernah ada perusahaan yang mau mempromosikan keburukan dirinya. Pada tingkat ekstremnya, iklan malah bisa bekerja untuk memproduksi kesadaran palsu. Ia mampu membuat orang melupakan kebutuhan dasarnya, merancukan mana kebutuhan mana keinginan.

Pada hakikatnya iklan berfungsi sebagai media untuk mengombinasikan pesan yang relatif natural, yang lebih banyak terkait dengan nilai guna (use value) atas produk yang ditawarkan. Namun dalam perkembangannya kemudian terjadi pergeseran yang jauh, yakni lebih mengedepankan nilai citra (image value), misalnya berupa janji-janji simbolik tentang kemewahan, gaya hidup, dan hedonisme. Pergeseran ini yang kemudian menjadi pemicu terjadinya penjungkirbalikan logika produksi-konsumsi, karena pelbagai komoditas tak lagi diproduksi untuk memenuhi kebutuhan, melainkan justru malah sebaliknya, yaitu kebutuhan yang memang sengaja diciptakan.

Pergeseran dari untuk memenuhi kebutuhan ke kebutuhan yang sengaja di ciptakan membuat masyarakat terjebak dalam pola hidup konsumerisme dan hedonisme yang tinggi. Seperti bisa kita lihat pada masyarakat kita yang dengan bangganya memiliki handphone yang lebih dari satu bahkan ada yang lima. Penggunaan handphone orientasinya bukan lagi pada kegunaannya melainkan pada perlombaan untuk mengoleksi handphone keluaran terbaru walaupun dalam hal nilai gunanya sama. Makan di restoran siap saji seperti KFC, CFC, dll menjadi primadona kaum muda dan masyarakat Indonesia ketimbang makan masakan yang diolah sendiri di rumah. Memiliki tiga sampai lima buah mobil juga merupakan pemandangan yang juga biasa terjadi di Indonesia. Berkat bantuan iklan, kini kita begitu menjadi manusia yang mendambakan hidup konsumerisme dan hedonisme. Yang lebih ekstremnya lagi adalah menghalalkan segala cara untuk hidup seperti itu, contohnya tak usah muluk-muluk, coba saja kita lihat dari kehidupan para koruptor yang telah tertangkap oleh KPK yang tak bosan-bosan menghiasi wajah pemberitaan di negeri ini. Maling uang rakyat di anggap hal yang lumrah untuk memenuhi pola hidup konsumerisme dan hedonisme yang tinggi.

Sudah seharusnya sekarang kita membuang jauh-jauh mental budak, abdi, dan minder. Dan menyadari bahwa di balik tawa kita yang sumringah, kita sekarang sedang dijajah (di hegemoni) oleh asing. Sudah saatnya kita kritis dan terbebas dari propaganda-propaganda yang dilakukan oleh asing melalui iklan. Sudah saatnya kita sadar bahwa negeri kita adalah pasar bagi negara-negara kapitalisme. Karena hal yang sia-sia jika kita tiap hari mempertanyakan tentang 
merdeka bahkan kadang menuntutnya dan juga memperingati hari kemerdekaan setiap tahunnya, jika mental bobrok tetap dipelihara dan tetap merasa baik-baik saja, bahkan bahagia, walaupun hidup dalam ketergantungan total atas pihak asing. (*) 